Nader Ghaffari Khaligh*, Taraneh Mihankhah, Mohd Rafie Johan and Salam J.J. Titinchi

\title{
Microwave-assisted synthesis of pyrrolidinone derivatives using 1,1'-butylenebis(3-sulfo-3H- imidazol-1-ium) chloride in ethylene glycol
}

https://doi.org/10.1515/gps-2019-0004

Received May 25, 2018; accepted September 21, 2018.

\begin{abstract}
The energy efficiency of the microwave-assisted synthesis of pyrrolidinones was demonstrated using catalytic loading of 1,1'-butylene-bis(3-sulfo-3H-imidazol1-ium) chloride as a sulfonic acid functionalized ionic liquid in ethylene glycol as green solvent. The effect of electron donating and electron withdrawing groups on aniline derivatives was studied under conventional heating and microwave irradiation. Furthermore, the cation effect of ionic liquids containing sulfonic groups on the catalytic efficiency for the synthesis of ethyl-1-phenyl2-(4-chlorophenyl)-4-hydroxy-5-oxo-2,5-dihydro-1H-pyrrole-3-carboxylate was investigated under conventional heat. The experimental results exhibited that there is a relationship between catalytic efficiency and the number of sulfonic groups and imidazolium moieties linked by carbon spacer.
\end{abstract}

Keywords: microwave-assisted synthesis; pyrrolidinone; sulfonic-functionalized ionic liquid; electronic effect; cation effect

\section{Introduction}

Microwave irradiation is known as a non-conventional energy source that has been broadly applied in

\footnotetext{
* Corresponding author: Nader Ghaffari Khaligh, Nanotechnology and Catalysis Research Center,3rd Floor, Block A, Institute of Postgraduate Studies, University of Malaya, 50603 Kuala Lumpur, Malaysia, e-mail: ngkhaligh@gmail.com and alsongkhaligh@um.edu.my, Tel.: +98-21-6643-1738; Fax: +98-21-6693-4046 Mohd Rafie Johan, Nanotechnology and Catalysis Research Center,3rd Floor, Block A, Institute of Postgraduate Studies, University of Malaya, 50603 Kuala Lumpur, Malaysia Taraneh Mihankhah, Environmental Research Laboratory, Department of Water and Environmental Engineering, School of Civil Engineering, Iran University of Science and Technology, 16765-163, Tehran, Iran Salam J.J. Titinchi, Department of Chemistry, University of the Western Cape, 7535, Cape Town, South Africa
}

organic synthesis due to important advantages of this technology including spectacular acceleration, higher yield under milder reaction conditions, higher purity of product by reducing unwanted side reactions and the by-products, the reduction in utilization of solvents or reagents, and the reduction of environmental pollution. The effect of microwave irradiation can be supposed a combination of thermal effects viz. heating rate and "hot spots" along with specific effects, medium effects (the selective absorption of radiation by polar chemicals), superheating effect, and reaction mechanism effects. The reader can find excellent reviews microwave-assisted cycloaddition reactions have been reviewed in the literature [1], heterocyclic chemistry [2,3], homogeneous and heterogeneous catalysis [4,5], medicinal chemistry, drug discovery and combinatorial chemistry [6-8], and green chemistry [9]. The controlled microwave-assisted organic synthesis usually needs shorter heating time, simple apparatus setup, which lead to the lowering of the energy costs. In general, this enabling technology is continuing to be an efficient and practical technique in the organic and medicinal chemistry communities [10-12].

The task-specific ionic liquids (TSILs) have displayed promising results in a variety of areas including synthesis, catalysis, gas absorption, analysis, electrochemistry, spectroscopy, extracting, and material science due to very diverse, tunable, and designable properties [13-15]. The functional groups can be incorporated into either the anion or the cation of the IL and their application efficiency can be studied on the basis of their specific interactions. Immiscibility of ILs with some organic solvents allows the simple separation of the catalysts and the respective products in different phases which lead to avoid the tedious and expensive procedures along with consuming high volumes of volatile, flammable, and toxic solvents $[16,17]$.

The 2-pyrrolidinone core is a well-known heterocyclic scaffold which is found in natural products and pharmaceuticals such as piracetam, oxiracetam, aniracetam, nefiracetam, and levetiracetam. They have been interested over the past few years owing to 
their notable pharmaceutical effects and the promising results in medicinal chemistry, and drug designing [18]. 2-Pyrrolidinone derivatives substituted in position-4 were able to reduce the extracellular glutamate level, therefore effective for the prophylaxis and treatment of a large number of disorders such as stroke [19]. This fascinating scaffold has diverse pharmacological activities including antibacterial, antifungal, anticancer and anticonvulsant [20-23]; therefore, many procedures for the preparation of substituted pyrrolidinone have been reported and also their various reactions offer great scope in the field of medicinal chemistry [24-30].

The imidazole-based ionic liquids containing $\mathrm{SO}_{3} \mathrm{H}-$ functionalized have been well-known to exhibit the catalysis activity for the multicomponent reactions [31-36]. Herein, we describe the synthesis of the 2-Pyrrolidinone derivatives in the presence of $[\mathrm{BBSI}] \mathrm{Cl}$ as an efficient catalyst with a focus on the 6th principle of the twelve principles of green chemistry viz: design for energy efficiency. Also, the structure-activity relationship (SAR) of a variety of ionic liquids containing a common anion was studied.

\section{Experiment}

\subsection{General}

Unless specified, all chemicals were analytical grade and purchased from Merck, Aldrich, and Fluka Chemical Companies and used without further purification. Products were characterized by their physical constant and FT-IR, NMR and elemental analysis. All the reactions were carried out in the Discover SP microwave synthesizer which was purchased from CEM, Ltd. and the maximum output microwave power is $300 \mathrm{~W}$. The purity determination of the substrates and products or the reaction monitoring were accompanied by TLC using silica gel SIL G/UV 254 plates or GC-MS on an Agilent 6890GC/5973MSD analysis instrument under $70 \mathrm{eV}$ conditions. The FT-IR spectra were recorded on a Perkin Elmer 781 Spectrophotometer using $\mathrm{KBr}$ pellets for solid and neat for liquid samples in the range of 4000-400 $\mathrm{cm}^{-1}$. The ${ }^{1} \mathrm{H}$ and ${ }^{13} \mathrm{C}$ NMR spectra were recorded with Bruker Avance III $600 \mathrm{MHz}$ and $400 \mathrm{MHz}$ instruments. Microanalyses were performed on a Perkin-Elmer 240-B microanalyzer. Melting points were recorded on a Büchi B-545 apparatus in open capillary tubes.

\subsection{Typical procedure for the synthesis of pyrrolidinones ( $2 a-q)$ at room temperature}

The diethyl acetylenedicarboxylate $(2.0 \mathrm{mmol}, 340 \mathrm{mg})$ and [BBSI]Cl catalyst $(1.0 \mathrm{mmol} \%, 9.1 \mathrm{mg})$ were mixed in $2 \mathrm{~mL}$ ethanol. Then, the aromatic aldehyde and primary amine were added and the mixture was stirred at room temperature for $60 \mathrm{~min}$. After the completion of the reaction (monitored by TLC), the crude products were extracted by EtOAc $(3 \times 10 \mathrm{~mL})$. The extracted organic phases were collected and dried on anhydrous $\mathrm{Na}_{2} \mathrm{SO}_{4}$. The solvent was removed by a rotary evaporator. The purification of the product was performed by flash chromatography or recrystallization from hot ethanol. The spectra and physical data of known products were consistent with those previously reported in the literature.

\subsection{Typical procedure for the controlled microwave-assisted synthesis of pyrrolidinones (3a-q)}

A mixture of the aryl aldehyde $(2.0 \mathrm{mmol})$, arylamine derivatives $(2.0 \mathrm{mmol})$, diethyl acetylenedicarboxylate $(2.0 \mathrm{mmol}, 340 \mathrm{mg})$ and [BBSI]Cl catalyst $(1.0 \mathrm{mmol} \%$, $9.1 \mathrm{mg}$ ) was stirred in $2 \mathrm{~mL}$ ethylene glycol in a $10 \mathrm{~mL}$ sealed microwave reactor of Discover SP microwave synthesizer. The reaction mixture was subjected to microwave irradiation of $100 \mathrm{~W}$ at room temperature for $5 \mathrm{~min}$. After cooling to room temperature, the crude products were extracted by EtOAc $(3 \times 10 \mathrm{~mL})$ and the extracted organic phases were dried over anhydrous $\mathrm{Na}_{2} \mathrm{SO}_{4}$. The solvent was removed by a rotary evaporator. The pure products were obtained by flash chromatography or recrystallized from hot ethanol.

\subsection{The spectral data of some known products}

Ethyl-1-phenyl-2-(4-chlorophenyl)-4-hydroxy-5-oxo-2,5dihydro-1H-pyrrole-3-carboxylate (3a): FT-IR $(\mathrm{KBr}) v_{\max }=$ 3300, 1715, 1690, 1660, 1495, 1370, 1310, 1255, 1210, 1135, $760,520 \mathrm{~cm}^{-1} ;{ }^{1} \mathrm{H}$ NMR (400 MHz, $\left.\mathrm{CDCl}_{3}\right) \delta=1.20(\mathrm{t}, J=7.0$ $\mathrm{Hz}, 3 \mathrm{H}$ ), 4.20 (q, $J=7.0 \mathrm{~Hz}, 2 \mathrm{H}), 5.72(\mathrm{~s}, 1 \mathrm{H}), 7.11-7.17$ (m, $3 \mathrm{H}), 7.22-7.30(\mathrm{~m}, 4 \mathrm{H}), 7.43(\mathrm{~d}, J=8.0 \mathrm{~Hz}, 2 \mathrm{H}), 9.04(\mathrm{br} \mathrm{s}, 1 \mathrm{H})$ ppm; ${ }^{13} \mathrm{C}$ NMR (100 MHz, $\mathrm{CDCl}_{3}$ ) $\delta=13.6,60.5,61.1,112.5$, 122.0, 125.8, 128.6, 128.7, 128.9, 133.4, 134.1, 135.8, 156.3, 162.4, 164.6 ppm; Anal. Calcd. for $\mathrm{C}_{19} \mathrm{H}_{16} \mathrm{ClNO}_{4}: \mathrm{C}, 63.78 ; \mathrm{H}$, 4.51; N, 3.91; Found: C, 63.73; H, 4.49; N, 3.86\%. 
Ethyl-1-phenyl-4-hydroxy-5-oxo-2-(4trifluoromethylphenyl)-2,5-dihydro-1H-pyrrole-3carboxylate (3d): FT-IR (KBr) $v_{\max }=3300,2985,1725$, 1690, 1595, 1500, 1445, 1425, 1375, 1330, 1260, 1165, 1120, $1020 \mathrm{~cm}^{-1} ;{ }^{1} \mathrm{H}$ NMR (400 MHz, $\left.\mathrm{CDCl}_{3}\right) \delta=1.19$ (t, $J=7.2 \mathrm{~Hz}$, $3 \mathrm{H}), 4.20$ (q, $J=7.2 \mathrm{~Hz}, 2 \mathrm{H}), 5.81(\mathrm{~s}, 1 \mathrm{H}), 7.12(\mathrm{t}, J=7.6 \mathrm{~Hz}$, $1 \mathrm{H}), 7.30(\mathrm{t}, J=7.6 \mathrm{~Hz}, 2 \mathrm{H}), 7.38(\mathrm{~d}, J=8.0 \mathrm{~Hz}, 2 \mathrm{H}), 7.47$ (d, $J=8.0 \mathrm{~Hz}, 2 \mathrm{H}), 7.53(\mathrm{~d}, J=8.0,2 \mathrm{H}), 9.10(\mathrm{br} \mathrm{s}, 1 \mathrm{H}) ;{ }^{13} \mathrm{C} \mathrm{NMR}$ $\left(150 \mathrm{MHz}, \mathrm{CDCl}_{3}\right) \delta=14.2,60.2,60.4,112.0,122.7,124.3 U_{\mathrm{C}-\mathrm{F}}$ = $244.7 \mathrm{~Hz})$, , 125.5, 125.7, 125.9, 128.4, 128.7, 129.0, 129.1, 129.2, 136.4, 142.0, 152.5, 162.3, 164.2 ppm; Anal. Calcd. for $\mathrm{C}_{20} \mathrm{H}_{16} \mathrm{~F}_{3} \mathrm{NO}_{4}$ : C, 61.38; H, 4.12; N, 3.58; Found: C, 61.42; $\mathrm{H}, 4.16 ; \mathrm{N}, 3.53 \%$.

Ethyl-1-(4-nitrophenyl)-4-hydroxy-5-oxo-2-(4trifluoromethylphenyl)-2,5-dihydro-1H-pyrrole-3carboxylate (3o): FT-IR (KBr) $v_{\max }=3320,2995,1740$, 1690, 1600, 1515, 1450, 1425, 1365, 1330, 1265, 1220, 1190, $1165,1120,1070,1020 \mathrm{~cm}^{-1} ;{ }^{1} \mathrm{H}$ NMR $\left(600 \mathrm{MHz}, \mathrm{CDCl}_{3}\right) \delta=$ $1.22(\mathrm{t}, \mathrm{J}=7.2 \mathrm{~Hz}, 3 \mathrm{H}), 4.23(\mathrm{q}, J=7.2 \mathrm{~Hz}, 2 \mathrm{H}), 5.88(\mathrm{~s}, 1 \mathrm{H})$, $7.40(\mathrm{~d}, J=8.0 \mathrm{~Hz}, 2 \mathrm{H}), 7.57(\mathrm{~d}, J=8.0 \mathrm{~Hz}, 2 \mathrm{H}), 7.76(\mathrm{~d}$, $J=9.2 \mathrm{~Hz}, 2 \mathrm{H}), 8.14(\mathrm{~d}, J=9.2 \mathrm{~Hz}, 2 \mathrm{H}) \mathrm{ppm} ;{ }^{13} \mathrm{C}$ NMR $(150$ $\left.\mathrm{MHz}, \mathrm{CDCl}_{3}\right) \delta=14.0,60.5,61.9,113.5,120.6,123.5\left(U_{\mathrm{C}-\mathrm{F}}=\right.$ $265.0 \mathrm{~Hz}), 126.0,126.1,127.8,130.9,131.2,131.5,138.7$, 141.6, 144.4, 155.8, 163.0, 164.5 ppm; Anal. Calcd. for $\mathrm{C}_{20} \mathrm{H}_{15} \mathrm{~F}_{3} \mathrm{~N}_{2} \mathrm{O}_{6}: \mathrm{C}, 55.05$; H, 3.46; N, 6.42; Found: C, 55.03; $\mathrm{H}, 3.42$; N, 6.38\%.

Ethyl-1-p-tolyl-4-hydroxy-5-oxo-2-(4trifluoromethylphenyl)-2,5-dihydro-1H-pyrrole-3carboxylate (3p): FT-IR (KBr) $v_{\max }=3305,2985,1730,1690$, 1660, 1515, 1445, 1420, 1370, 1325, 1255, 1215, 1170, 1145, 1110, 1065, $1020 \mathrm{~cm}^{-1}$; ${ }^{1} \mathrm{H}$ NMR (400 MHz, $\left.\mathrm{CDCl}_{3}\right) \delta=1.19$ (t, $J=7.2 \mathrm{~Hz}, 3 \mathrm{H}), 2.26$ (s, 3H), 4.20 (q, $J=7.2 \mathrm{~Hz}, 2 \mathrm{H}), 5.77$ (s, 1H), 7.09 (d, $J=8.4 \mathrm{~Hz}, 2 \mathrm{H}), 7.34(\mathrm{~d}, J=8.4 \mathrm{~Hz}, 2 \mathrm{H}), 7.37$ (d, $J=8.0 \mathrm{~Hz}, 2 \mathrm{H}), 7.53$ (d, $J=8.0 \mathrm{~Hz}, 2 \mathrm{H}), 9.11$ (br s, $1 \mathrm{H}$ ) ppm; ${ }^{13} \mathrm{C}$ NMR (100 MHz, $\left.\mathrm{CDCl}_{3}\right) \delta=13.8,20.7,61.0,61.2$, $\left.112.3,122.1,123.8 U_{\mathrm{C}-\mathrm{F}}=270.8 \mathrm{~Hz}\right), 125.5,125.6,125.7,127.9$, 129.5, 130.0, 130.4, 130.8, 133.2, 136.0, 139.5, 156.6, 162.5, 164.6 ppm; Anal. Calcd. for $\mathrm{C}_{21} \mathrm{H}_{18} \mathrm{~F}_{3} \mathrm{NO}_{4}$ : C, 62.22; H, 4.48; N, 3.46; Found: C, 62.19; H, 4.42; N, 3.38\%.

Ethyl-1-(4-methoxyphenyl)-4-hydroxy-5-oxo-2(4-trifluoromethylphenyl)-2,5-dihydro-1H-pyrrole-3carboxylate (3q): FT-IR (KBr) $v_{\max }=3300,1715,1690,1660$, 1495, 1370, 1310, 1255, 1210, 1135, 760, $520 \mathrm{~cm}^{-1}$; ${ }^{1} \mathrm{H}$ NMR $\left(400 \mathrm{MHz}, \mathrm{CDCl}_{3}\right) \delta=1.14$ (t, $\left.J=7.2 \mathrm{~Hz}, 3 \mathrm{H}\right), 3.69(\mathrm{~s}, 3 \mathrm{H})$, $4.15(q, \mathrm{~J}=7.2 \mathrm{~Hz}, 2 \mathrm{H}), 5.72(\mathrm{~s}, 1 \mathrm{H}), 6.77(\mathrm{~d}, J=9.2 \mathrm{~Hz}, 2 \mathrm{H})$, $7.28(\mathrm{t}, J=9.2 \mathrm{~Hz}, 2 \mathrm{H}), 7.33(\mathrm{~d}, J=8.4 \mathrm{~Hz}, 2 \mathrm{H}), 7.50(\mathrm{~d}, J=$ $8.4 \mathrm{~Hz}, 2 \mathrm{H}) \mathrm{ppm} ;{ }^{13} \mathrm{C}$ NMR $\left(100 \mathrm{MHz}, \mathrm{CDCl}_{3}\right) \delta=14.4,55.6$, 60.2, 61.0, 111.8, 114.4, $\left.124.0 \mathrm{U}_{\mathrm{C}-\mathrm{F}}=269 \mathrm{~Hz}\right), 125.5,125.6$, 125.8, 128.4, 128.5, 128.7, 129.0, 129.2, 129.3, 142.2, 153.8, 157.4, 162.4, 164.2 ppm; Anal. Calcd. for $\mathrm{C}_{21} \mathrm{H}_{18} \mathrm{~F}_{3} \mathrm{NO}_{5}$ : C, 59.86; H, 4.31; N, 3.32; Found: C, 58.82; H, 4.25; N, 3.29\%.

\section{Results and discussion}

In order to study and achieve the optimized reaction conditions, the 4-chlorobenzaldehyde, aniline, and diethyl acetylenedicarboxylate were chosen as the model reactants and their one-pot reaction was studied at room temperature in the absence of catalyst and under solvent free conditions. The model reaction was conducted by the planetary ball mill which afforded the corresponding product in trace yield after $4 \mathrm{~h}$ at room temperature (Table 1 , entry 1). In the presence of water as green solvent, ethyl1-phenyl-2-(4-chlorophenyl)-4-hydroxy-5-oxo-2,5-dihydro$1 \mathrm{H}$-pyrrole-3-carboxylate (3a) was afforded in 20\% yield in catalyst-free condition (Table 1, entry 2). An improvement was displayed when the reaction was conducted in ethanol because the model reactants were more soluble in ethanol than in water (Table 1, entry 3). When $0.5 \mathrm{~mol} \%$ of [BBSI]Cl was added to the model reaction in ethanol and the mixture was stirred for $2 \mathrm{~h}$ at room temperature, 3a afforded in 79\% yield (Table 1, entry 4). Increasing amount of catalyst led to a significant improvement in yield (Table 1, entry 5) while further reduction of the reaction time afforded a lower yield of $3 a$ (Table 1, entries 6 and 7).

To the best of our knowledge, no report exists concerning the use of sulfonic acid functionalized ionic liquid in a green solvent for the controlled microwaveassisted synthesis of pyrrolidinones; therefore, the model reaction was performed under microwave irradiation in ethanol at room temperature (Table 2, entries 1-3). A higher yield was obtained under microwave irradiation within a very shorter reaction time as it was expected (Table 2, entry 2) [37,38]. The 3a was obtained in $91 \%$ yield when amount of catalyst was decreased to $0.5 \mathrm{~mol} \%$ of [BBSI]

Table 1: Optimization of the synthesis of ethyl-1-phenyl-2-(4chlorophenyl)-4-hydroxy-5-oxo-2,5-dihydro-1H-pyrrole-3-carboxylate (3a) under a variety of reaction conditions. ${ }^{a}$

\begin{tabular}{lcccc}
\hline Entry & $\begin{array}{c}\text { Loading of [BBSI]Cl } \\
(\mathbf{m o l} \%)\end{array}$ & $\begin{array}{c}\text { Solvent } \\
(\mathbf{2} \mathbf{~ m L})\end{array}$ & $\begin{array}{c}\text { Reaction time } \\
(\mathbf{h})\end{array}$ & $\begin{array}{c}\text { Yield } \\
(\%)^{\mathrm{b}}\end{array}$ \\
\hline 1 & 0.0 & - & 4 & Trace $^{\mathrm{c}}$ \\
2 & 0.0 & $\mathrm{H}_{2} \mathrm{O}$ & 4 & 20 \\
3 & 0.0 & $\mathrm{EtOH} \mathrm{(96 \% )}$ & 4 & 26 \\
4 & 0.5 & EtOH (96\%) & 2 & 79 \\
5 & 1.0 & EtOH (96\%) & 1 & 89 \\
6 & 1.0 & EtOH (96\%) & $\mathbf{3 0}$ & $\mathbf{8 8}$ \\
7 & 1.0 & EtOH (96\%) & 20 min & 70 \\
\hline
\end{tabular}

${ }^{a}$ Reaction conditions: 4-chlorobenzaldehyde (1a) $(2.0 \mathrm{mmol})$, aniline $(2.0 \mathrm{mmol})$, diethyl acetylenedicarboxylate $(2.0 \mathrm{mmol})$, room temperature.

${ }^{\mathrm{b}}$ Isolated yield.

' Monitored by GC-MS. 
$\mathrm{Cl}$ (Table 2, entry 3). In general, polar solvents and ionic compounds are appropriate solvents for the microwaveassisted reactions [39]. Ethylene glycol exhibits a low vapor pressure and as a polar solvent thereby enhance

Table 2: Optimization of the synthesis of ethyl-1-phenyl-2-(4chlorophenyl)-4-hydroxy-5-oxo-2,5-dihydro-1H-pyrrole-3-carboxylate (2a) under microwave irradiation. ${ }^{\mathrm{a}}$

\begin{tabular}{|c|c|c|c|c|c|c|}
\hline Entry & $\begin{array}{l}\text { Loading of } \\
\text { [BBSI]Cl } \\
\text { (mol\%) }\end{array}$ & $\begin{array}{l}\text { Solvent } \\
(2 \mathrm{~mL})\end{array}$ & $M W(W)$ & $\begin{array}{c}\text { Temp. } \\
\left({ }^{\circ} \mathrm{C}\right)\end{array}$ & $\begin{array}{l}\text { Reaction } \\
\text { time (min) }\end{array}$ & $\begin{array}{l}\text { Yield } \\
(\%)^{b}\end{array}$ \\
\hline 1 & 1.0 & EtOH (96\%) & - & r.t. & 30 & 88 \\
\hline 2 & 1.0 & EtOH (96\%) & 100 & r.t. & 15 & 92 \\
\hline 3 & 0.5 & EtOH (96\%) & 100 & r.t. & 15 & 91 \\
\hline 4 & 0.5 & $\begin{array}{l}\text { Ethylene } \\
\text { glycol }\end{array}$ & 100 & r.t. & 5 & 91 \\
\hline 5 & 0.5 & $\begin{array}{l}\text { Ethylene } \\
\text { glycol }\end{array}$ & 150 & r.t. & 5 & 92 \\
\hline 6 & 0.5 & $\begin{array}{l}\text { Ethylene } \\
\text { glycol }\end{array}$ & 300 & r.t. & 5 & 85 \\
\hline 7 & 0.5 & $\begin{array}{l}\text { Ethylene } \\
\text { glycol }\end{array}$ & 100 & 50 & 5 & 91 \\
\hline
\end{tabular}

${ }^{a}$ Reaction conditions: 4-chlorobenzaldehyde (1a) $(2.0 \mathrm{mmol})$, aniline $(2.0 \mathrm{mmol})$, diethyl acetylenedicarboxylate $(2.0 \mathrm{mmol})$.

${ }^{\mathrm{b}}$ Isolated yield. its suitability for microwave heating. A significant improvement was obtained in the reaction time when ethylene glycol was used as a solvent (Table 2, entry 4). Increasing the power of microwave irradiation led to a drop in the yield of $\mathbf{3 a}$ (Table 2, entries 5 and 6), while we observed no improvement in 3a yield within a longer reaction time (Table 2, entry 7 ).

It is supposed that the improvements in yield and an increase in the reaction rate is related to the peculiarities of the substance heating under microwave exposure, which lies in the rapid and uniform heating of the whole reaction mixture. The heat generated in their volume is a result of direct interaction of electromagnetic irradiation with the reactants, ionic liquid, and solvent. Therefore microwave heating is an effective tool for promoting the multi-component reactions and using energy more efficiently.

Then, a variety of aldehydes $\mathbf{1}(\mathbf{a}-\mathbf{q})$ and amines were investigated under optimized conditions for both methods viz. conventional (A) and non-conventional (B) processes and as shown in Table 3, the substituted pyrrolidinones (3a-m) were afforded in good to excellent yield (Scheme 1). The electron-withdrawing substituents on aromatic ring of aryl aldehydes afforded higher yields of pyrrolidinones than electron-donating substituents at

Table 3: Synthesis of 2-pyrrolidinones in the presence of [BBSI]Cl under optimized reaction conditions. ${ }^{a}$

\begin{tabular}{|c|c|c|c|c|c|c|c|}
\hline \multirow{2}{*}{ Entry } & \multirow{2}{*}{ Aldehyde (1) } & \multirow{2}{*}{ amine (2) } & \multirow{2}{*}{ Product (3) } & \multicolumn{2}{|c|}{ Yield (\%) ${ }^{b}$} & \multicolumn{2}{|c|}{ Melting point $\left({ }^{\circ} \mathrm{C}\right)$} \\
\hline & & & & Method A & Method B & Found & Reported (ref.) \\
\hline 1 & $4-\mathrm{Cl}-\mathrm{C}_{6} \mathrm{H}_{4}^{-}$ & $\mathrm{C}_{6} \mathrm{H}_{5}-\mathrm{NH}_{2}$ & $\mathrm{a}$ & 88 & 91 & $188-190$ & $190-192(40)$ \\
\hline 2 & $\mathrm{C}_{6} \mathrm{H}_{5}^{-}$ & $\mathrm{C}_{6} \mathrm{H}_{5}-\mathrm{NH}_{2}$ & $\mathrm{~b}$ & 86 & 90 & $174-176$ & $174-176(40)$ \\
\hline 3 & 4- $\mathrm{CH}_{3}-\mathrm{C}_{6} \mathrm{H}_{4}^{-}$ & $\mathrm{C}_{6} \mathrm{H}_{5}-\mathrm{NH}_{2}$ & c & 84 & 88 & $180-182$ & $179-181(42)$ \\
\hline 4 & $4-\mathrm{CF}_{3}-\mathrm{C}_{6} \mathrm{H}_{4}^{-}$ & $\mathrm{C}_{6} \mathrm{H}_{5}-\mathrm{NH}_{2}$ & $d$ & 94 & 97 & $170-172$ & $172-174(41)$ \\
\hline 5 & $4-\mathrm{CH}_{3} \mathrm{O}-\mathrm{C}_{6} \mathrm{H}_{4}-$ & $\mathrm{C}_{6} \mathrm{H}_{5}-\mathrm{NH}_{2}$ & $\mathrm{e}$ & 82 & 90 & $140-142$ & $138-140(40)$ \\
\hline 6 & $2-\mathrm{CH}_{3} \mathrm{O}-\mathrm{C}_{6} \mathrm{H}_{4}-$ & $\mathrm{C}_{6} \mathrm{H}_{5}-\mathrm{NH}_{2}$ & $f$ & 77 & 84 & $190-192$ & $193-195(41)$ \\
\hline 7 & 4- $\mathrm{HO}-\mathrm{C}_{6} \mathrm{H}_{4}^{-}$ & $\mathrm{C}_{6} \mathrm{H}_{5}-\mathrm{NH}_{2}$ & $\mathrm{~g}$ & 81 & 90 & $240-242$ & $243-245(42)$ \\
\hline 8 & 4- $\mathrm{NO}_{2}-\mathrm{C}_{6} \mathrm{H}_{4}^{-}$ & $\mathrm{C}_{6} \mathrm{H}_{5}-\mathrm{NH}_{2}$ & $\mathrm{~h}$ & 96 & 97 & $180-182$ & $181-183(42)$ \\
\hline 9 & $2-\mathrm{NO}_{2}-\mathrm{C}_{6} \mathrm{H}_{5}-$ & $\mathrm{C}_{6} \mathrm{H}_{5}-\mathrm{NH}_{2}$ & $\mathrm{i}$ & 91 & 95 & $175-177$ & $178-180(41)$ \\
\hline 10 & $2-\mathrm{Cl}-\mathrm{C}_{6} \mathrm{H}_{4}^{-}$ & $\mathrm{C}_{6} \mathrm{H}_{5}-\mathrm{NH}_{2}$ & j & 82 & 90 & $200-202$ & $204-207(42)$ \\
\hline 11 & $4-\mathrm{Br}-\mathrm{C}_{6} \mathrm{H}_{4}-$ & $\mathrm{C}_{6} \mathrm{H}_{5}-\mathrm{NH}_{2}$ & $\mathrm{k}$ & 88 & 93 & $190-192$ & $190-193(42)$ \\
\hline 12 & $\mathrm{C}_{6} \mathrm{H}_{5}^{-}$ & $\mathrm{C}_{6} \mathrm{H}_{5}-\mathrm{NH}_{2}$ & 1 & 81 & 90 & $190-191$ & $190-192(40)$ \\
\hline 13 & $3,4\left(\mathrm{OCH}_{2} \mathrm{O}\right) \mathrm{C}_{6} \mathrm{H}_{3}-$ & $\mathrm{C}_{6} \mathrm{H}_{5}-\mathrm{CH}_{2}-\mathrm{NH}_{2}$ & $\mathrm{~m}$ & 84 & 90 & $170-172$ & $170-172(40)$ \\
\hline 14 & $4-\left[\left(\mathrm{CH}_{3}\right)_{2} \mathrm{~N}\right]-\mathrm{C}_{6} \mathrm{H}_{4}^{-}$ & $\mathrm{C}_{6} \mathrm{H}_{5}-\mathrm{NH}_{2}$ & $\mathrm{n}$ & - & - & - & - \\
\hline 15 & $4-\mathrm{CF}_{3}-\mathrm{C}_{6} \mathrm{H}_{4}^{-}$ & 4- $\mathrm{NO}_{2}-\mathrm{C}_{6} \mathrm{H}_{4}^{-}$ & 0 & $52^{c}$ & 88 & $170-172$ & $175-177(41)$ \\
\hline 16 & $4-\mathrm{CF}_{3}-\mathrm{C}_{6} \mathrm{H}_{4}^{-}$ & 4- $\mathrm{CH}_{3}-\mathrm{C}_{6} \mathrm{H}_{4}^{-}$ & $\mathrm{p}$ & 82 & 92 & $172-173$ & $176-178(41)$ \\
\hline 17 & 4- $-\mathrm{CF}_{3}-\mathrm{C}_{6} \mathrm{H}_{4}^{-}$ & 4- $\mathrm{CH}_{3} \mathrm{O}-\mathrm{C}_{6} \mathrm{H}_{4}^{-}$ & $q$ & 83 & 92 & $165-167$ & $162-164(41)$ \\
\hline
\end{tabular}

${ }^{a}$ Reaction conditions for method A: aryl aldehyde (1) $(2.0 \mathrm{mmol})$, aniline $(2.0 \mathrm{mmol})$, diethyl acetylenedicarboxylate $(2.0 \mathrm{mmol})$, [BBSI]Cl (1.0 mol\%), ethanol (96\%) (2 mL), temperature (reflux), room temperature, reaction time (30 min).

Reaction conditions for method B: aryl aldehyde (1) $(2.0 \mathrm{mmol})$, aniline $(2.0 \mathrm{mmol})$, diethyl acetylenedicarboxylate $(2.0 \mathrm{mmol}),[\mathrm{BBSI}] \mathrm{Cl}(1.0$ mol\%), ethylene glycol ( $2 \mathrm{~mL})$, microwave power (100 W), room temperature, reaction time (5 min).

bIsolated yield.

cReaction time (240 min). 
the same position (Table 3, entries 4 and $8 v s .5$ ) probably because the electrophilic property of aryl aldehyde increase [43]. No decomposition and isomerization were observed when the acid sensitive aldehydes were treated with aniline and diethyl acetylenedicarboxylate under optimal conditions (Table 3, entries 5 and 13). A few spots along with aryl aldehyde spot was observed on TLC when 4-(dimethylamino)-benzaldehyde (1n) was utilized as aryl aldehyde under optimized conditions in both method A and $\mathrm{B}$ and the corresponding product was not isolated (Table 3, entry 14) which may be owing to deactivation of 1n via resonance stabilization in the presence of [BBSI]Cl (Scheme 2).

The effect of electron-donating and electronwithdrawing substituents in para-position of aniline derivatives were studied for the reaction 4-triflourobenzaldeyde, diethyl acetylenedicarboxylate, and Furthermore, A variety of aryl amines containing electron-donating and electron-withdrawing substituents reacted with 4-trifluoro benzaldehyde and diethyl acetylenedicarboxylate through method A and

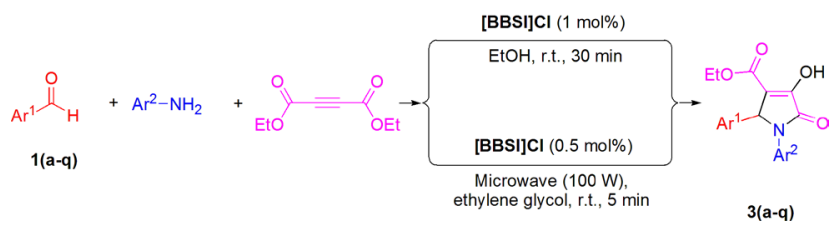

Scheme 1: Synthesis of pyrrolidinone derivatives in the presence of [BBSI]Cl under optimal conditions.
B under optimal conditions (Table 3, entries 15-17). The results demonstrated that the electron-withdrawing groups deactivated amino group and led to decrease the product yield and the reaction rate (Table 4, entry 15), while the electron-donating groups activated amino group and afforded a high yield of the corresponding products under optimal reaction conditions (Table 4, entries 16 and 17).

A possible mechanism is shown in Scheme 3. In the first step, the carbonyl group of aldehyde is activated by $\mathrm{C}-2$ hydrogen atom of imidazole moieties and the acidic hydrogen of sulfonic groups of [BBSI]Cl through the formation of hydrogen bond. As shown in Scheme 3, the [BBSI]Cl can probably act as dehydrating agents which will facilitate the formation of imine (I) from the reaction of as-activated aryl aldehyde and arylamine $[44,45]$. The addition reaction of water and diethyl acetylenedicarboxylate forms the intermediate

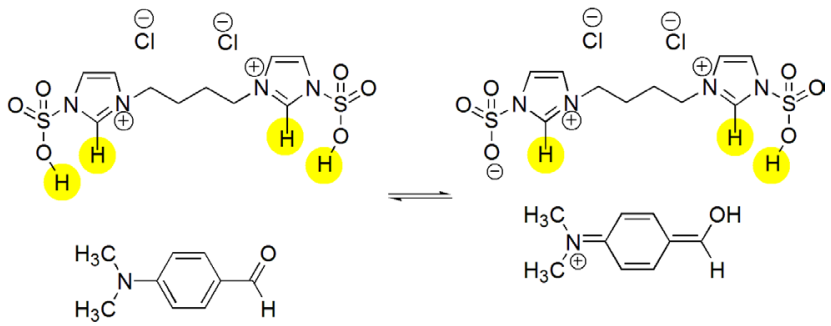

Scheme 2: Plausible deactivation of 4-(dimethylamino) benzaldehyde for the imine (Schiff base) formation in the presence of $[\mathrm{BBSI}] \mathrm{Cl}$ under optimized reaction conditions.

Table 4: The comparative study of present vs. previously reported methodology for the synthesis of ethyl-1,2-diphenyl-4-hydroxy-5-oxo2,5-dihydro-1H-pyrrole-3-carboxylate (2b).

\begin{tabular}{|c|c|c|c|c|c|c|c|c|}
\hline Entry & Catalyst & $\begin{array}{l}\text { Catalyst loading } \\
\text { (mol\%) }\end{array}$ & Solvent & $\begin{array}{l}\text { Temp. } \\
\left({ }^{\circ} \mathrm{C}\right)\end{array}$ & $\begin{array}{l}\text { Reaction time } \\
\text { (h) }\end{array}$ & Yield (\%) & Recyclable & Ref. \\
\hline 1 & - & - & Ethanol/ $\mathrm{H}_{2} \mathrm{O}(1: 1 \mathrm{v} / \mathrm{v})$ & r.t. & 15 & 87 & - & 46 \\
\hline 2 & $\begin{array}{l}\text { Citric acid mono } \\
\text { hydrate }\end{array}$ & 200 & Ethanol & r.t. & 10 & 85 & No & 42 \\
\hline 3 & $\begin{array}{l}\text { Citric acid mono } \\
\text { hydrate }\end{array}$ & 200 & Ethanol & $40(\text { US, } 100 \mathrm{~W})^{\mathrm{b}}$ & $20 \mathrm{~min}$ & 90 & No & 42 \\
\hline 4 & $\begin{array}{l}p \text {-toluenesulfonic } \\
\text { acid }\end{array}$ & 20 & Ethanol & r.t. & 48 & 62 & No & 29 \\
\hline 5 & Lactic acid & $1140(1 \mathrm{~mL})$ & $\begin{array}{l}\text { Lactic acid (85\% wt/ } \\
\text { wt) }\end{array}$ & 30 & 2 & $60^{\mathrm{a}}$ & No & 41 \\
\hline 6 & Glacial acetic acid & $1746(1 \mathrm{~mL})$ & Glacial acetic acid & 30 & 2 & $24^{\mathrm{a}}$ & No & 41 \\
\hline 7 & {$[\mathrm{BBSI}] \mathrm{Cl}$} & 1.0 & Ethanol (96\%) & r.t. & $30 \mathrm{~min}$ & 86 & Yes & This work \\
\hline 8 & {$[\mathrm{BBSI}] \mathrm{Cl}$} & 0.5 & Ethylene glycol & $\begin{array}{c}\text { r.t. }(M W, 100 \\
\text { W) }\end{array}$ & $5 \mathrm{~min}$ & 90 & Yes & This work \\
\hline
\end{tabular}

a 4-methylbenzaldehyde

${ }^{b}$ Ultrasound irradiation (power $100 \mathrm{~W}$ )

${ }^{\mathrm{c}}$ Microwave irradiation (power $100 \mathrm{~W}$ ) 


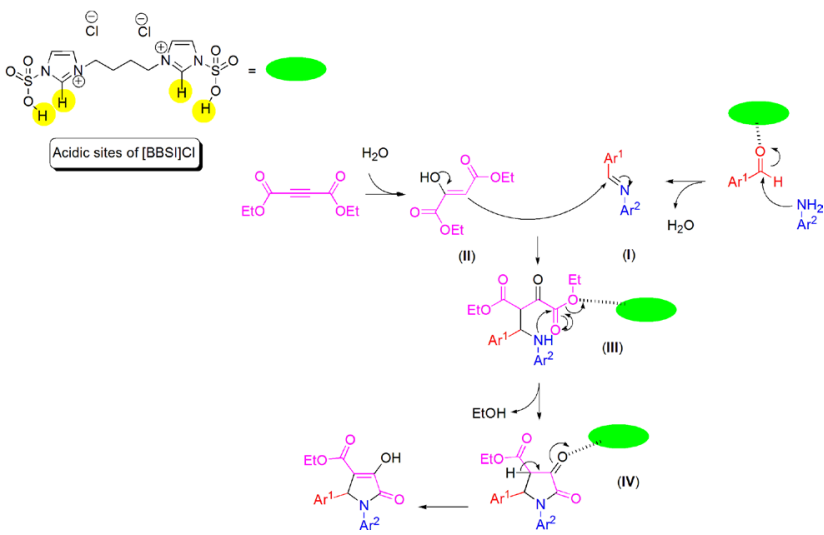

Scheme 3: The proposed mechanism for the synthesis of pyrrolidinone derivatives in the presence of $[\mathrm{BBSI}] \mathrm{Cl}$.

(II) followed by a Micheal addition of imine (I) and intermediate (II) which led to forming intermediate (III). An intermolecular cyclization and elimination of ethanol molecule afford the final product.

Finally, a $2.0 \mathrm{~g}$ scale of the model reactants was performed in the presence of $0.2 \mathrm{mmol}$ of $[\mathrm{BBSI}] \mathrm{Cl}$ in $20 \mathrm{~mL}$ of ethanol and ethylene glycol for method A and B, respectively; and 3a was isolated in $82 \%$ and $86 \%$ yield after $1.5 \mathrm{~h}$ and $10 \mathrm{~min}$.

Table 4 showed a comparison of present and reported methods in the literature. As observed, the catalytic efficiency of [BBIS] $\mathrm{Cl}$ is superior to the reported solventcatalysts in terms of catalyst loading, product yields, reaction times and recyclability (Table 4).

As shown in Table 5, the structure of the cationic moiety plays a crucial role on the catalytic efficiency of the ILs derived from pyrazinium, piperazinium, benzimidazolium, imidazolium cation containing chloride as counter anion as previously reported [46]. The [BBSI]Cl showed the best result comparing to pyrazinium and piperazinium ILs while the $[\mathrm{PiS}] \mathrm{Cl}$ and $[\mathrm{PzS}] \mathrm{Cl}$ exhibited a moderate catalytic activity which can be assigned to the presence of two sulfonic groups per IL molecules. Based on the catalytic efficiency of $[\mathrm{PzPS}] \mathrm{Cl}$ and $[\mathrm{PzS}] \mathrm{Cl}$, it seems that carbon spacer can be also considered as an important parameter on the catalytic efficiency of ILs (Table 5, entries 2 and 3). In general, it seems that the presence and number of the C-2 hydrogen and acid sites per imidazole-based IL, as well as the carbon spacer between the imidazolium moieties, increased their catalytic efficiency (Table 5, entries 4-6).

Recycling and reusability of the TSILs are very important for economic and environmental reasons when it comes to large-scale applications. After completion of
Table 5: Comparison of result obtained for the synthesis of ethyl1-phenyl-2-(4-chlorophenyl)-4-hydroxy-5-oxo-2,5-dihydro-1H-pyrrole-3-carboxylate (3a) in the presence of some sulfonic-functionalized ionic liquid containing mono- and di- cationic nucleus with [BBSI]Cl. ${ }^{a}$

\begin{tabular}{|c|c|c|c|}
\hline Entry & IL as solvent-catalyst & Abbreviation & Yield (\%) \\
\hline 1 & 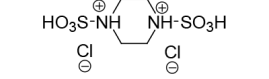 & {$[\mathrm{PiS}] \mathrm{Cl}$} & 66 \\
\hline 2 & & {$[\mathrm{PzS}] \mathrm{Cl}$} & 61 \\
\hline 3 & $\mathrm{SO}_{3} \mathrm{H}$ & {$[\mathrm{PzPS}] \mathrm{Cl}$} & 72 \\
\hline 4 & $\begin{array}{l}\mathrm{N}-\mathrm{SO}_{3} \mathrm{H} \\
\mathrm{Cl} \\
\ominus\end{array}$ & {$[\mathrm{DSI}] \mathrm{Cl}$} & 77 \\
\hline 5 & ${ }_{\Theta}^{\mathrm{Cl}} \mathrm{SO}_{3} \mathrm{H}$ & [DSBI]Cl & 80 \\
\hline 6 & $\stackrel{\mathrm{Cl}}{\ominus}$ & [BBSI]Cl & 89 \\
\hline
\end{tabular}

a Reaction conditions: 4-chlorobenzaldehyde (1a) $(2.0 \mathrm{mmol})$, aniline $(2.0 \mathrm{mmol})$, diethyl acetylenedicarboxylate $(2.0 \mathrm{mmol})$, ionic liquid containing sulfonic acid $(1.0 \mathrm{~mol} \% \mathrm{~mL})$, ethanol $(96 \%, 2 \mathrm{~mL})$, room temperature, reaction time (30 min).

$[\mathrm{PiS}] \mathrm{Cl}=$ Sulfonic acid-functionalized piperizanium chloride, $[\mathrm{PzS}]$ $\mathrm{Cl}=$ Sulfonic acid-functionalized pyrazinium chloride, $[\mathrm{PzPS}] \mathrm{Cl}=$ Sulfonic acid-functionalized pyrazinium propyl chloride, $[\mathrm{DSI}] \mathrm{Cl}=$ Sulfonic acid-functionalized imidazolium chloride.

the reaction, the solvent was removed in vacuum and the desired pyrrolidinones were readily extracted using EtOAc. The residue was recharged with new model reactants for the next run. The desired product was afforded in an average $82 \%$ and $86 \%$ yield for three successive runs in method A and B, respectively. The recycled [BBSI]Cl exhibited almost a constant catalytic activity even after three sequential runs. Furthermore, the ${ }^{1} \mathrm{H}$ NMR analysis of recycled [BBSI]Cl showed no considerable change under the present workup after the third run (Figures 1 and 2).

\section{Conclusion}

In summary, the catalytic efficiency of [BBSI]Cl and the energy efficiency of microwave irradiation were approved for the synthesis of pyrrolidinone derivatives. The advantages of current protocol included simple experimental and sustainable procedure, high reaction rate, good to excellent yield, and recyclability of the 


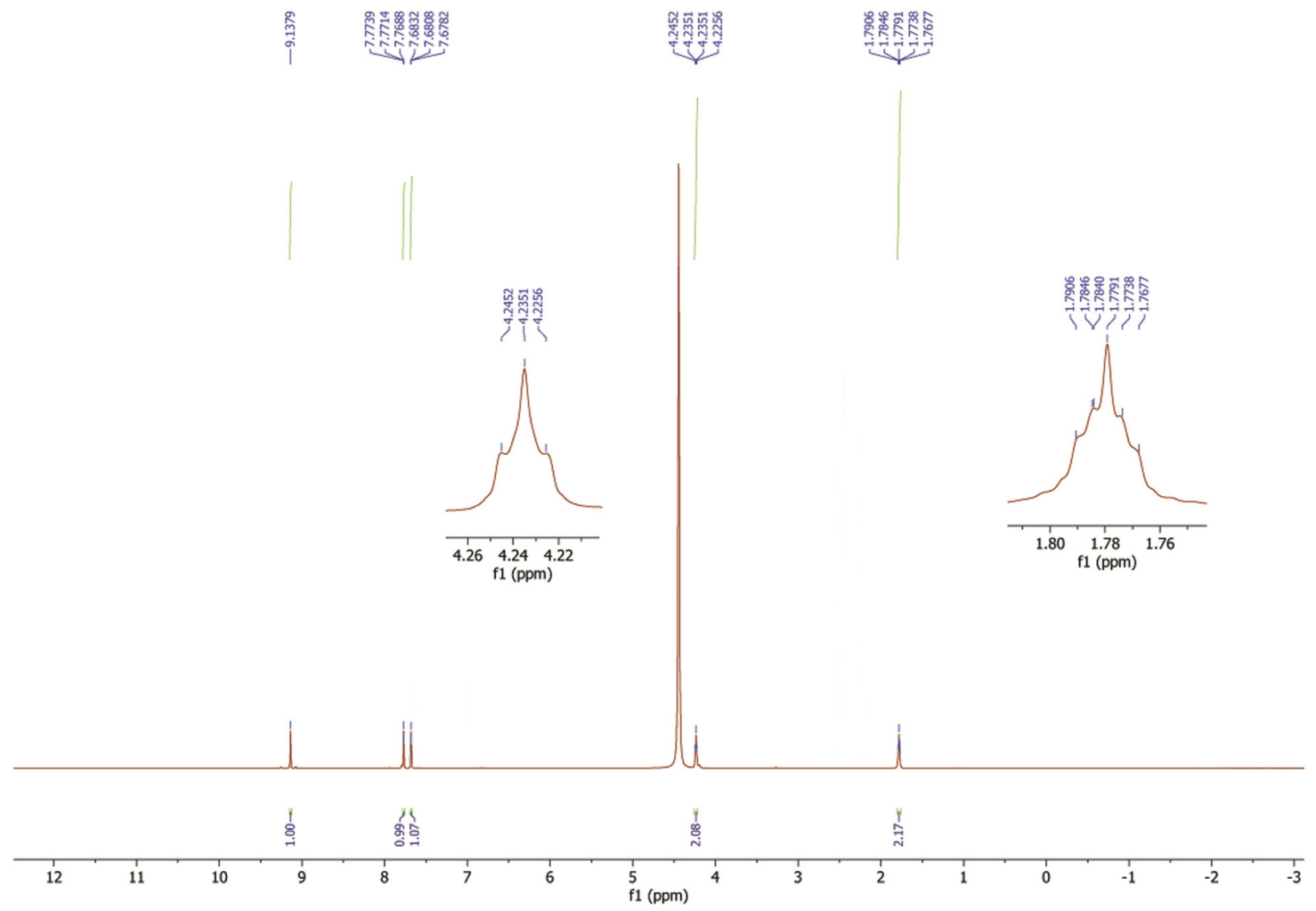

Figure 1: ${ }^{1} \mathrm{H}$ NMR of $[\mathrm{BBSI}] \mathrm{Cl}$ after the second run of the reaction under optimized reaction conditions.

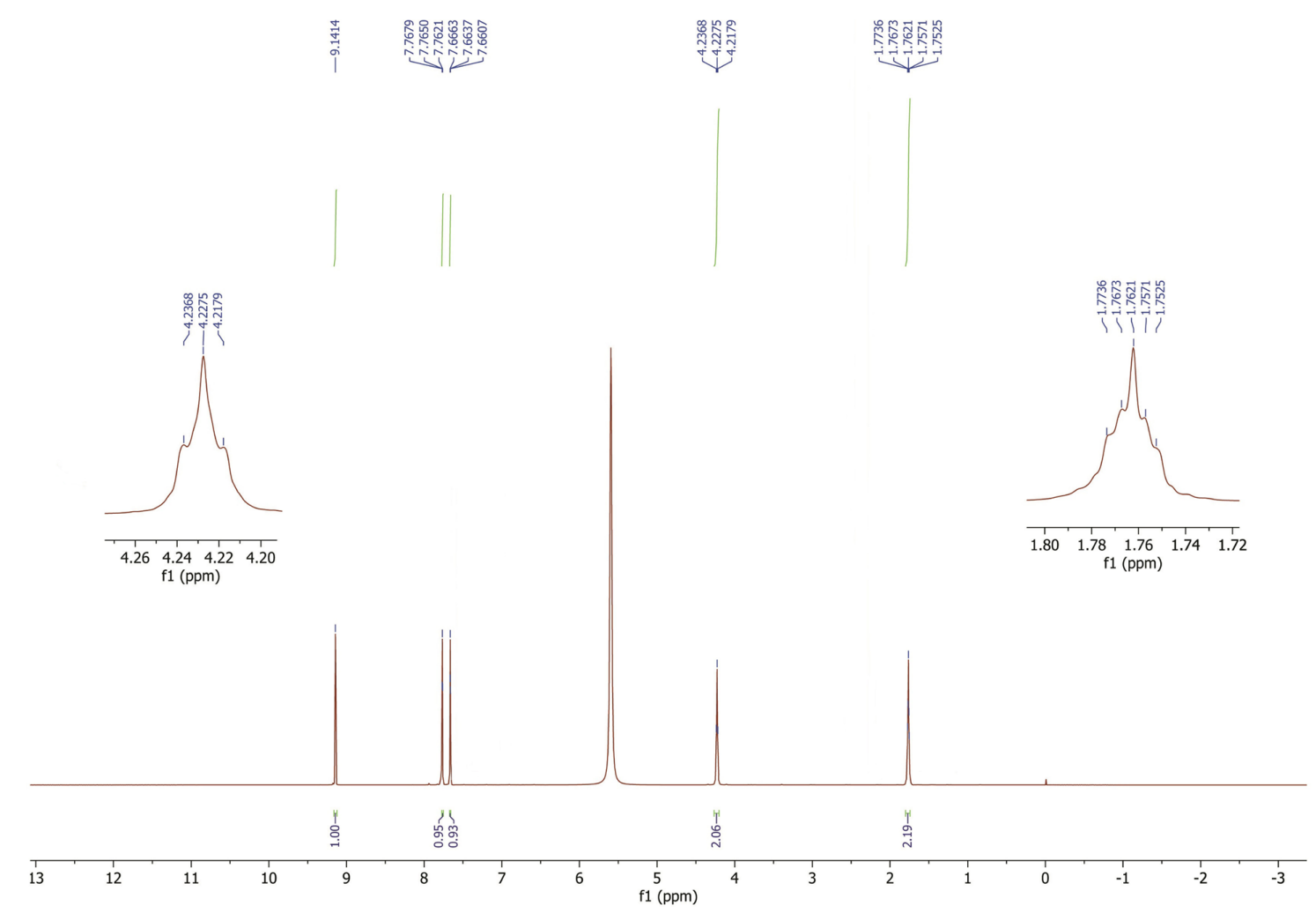

Figure 2: ${ }^{1} \mathrm{H}$ NMR of $[\mathrm{BBSI}] \mathrm{Cl}$ after the third run of the reaction under optimized reaction conditions. 
ionic liquid. Its application for the one-pot multi components reaction has highlighted the importance of task-specific ionic liquids (TSILs) as efficient catalyst and microwave irradiation as a green energy in organic synthesis, and we hope that the present method will find applications in academic and industrial processes owing to its broad substrate scope, improved yields, time saver, energy efficiency, and environmentally friendly transformation.

Acknowledgements: This work was supported by NANOCAT RU-Geran (Project no. RU001-2018) for Scientific Research from the University of Malaya, Malaysia. The authors are grateful to staff members in the Analytical and Testing Center of Iran University of Science and Technology for partial support.

\section{References}

[1] de la Hoz A., Díaz-Ortiz A., Moreno A., Langa F., Cycloadditions under microwave irradiation conditions: Methods and applications. Eur. J. Org. Chem., 2000, 4, 3659-3673.

[2] Xu Y., Guo Q.X., Syntheses of heterocyclic compounds under microwave irradiation. Heterocycles, 2004, 63, 903-974.

[3] Romanova N.N., Kudan P.V., Gravis A.G., Bundel Y.G., The use of microwave activation in the chemistry of heterocyclic compounds. (Review). Chem. Heterocycl. Compd., 2000, 36, 1130-1140.

[4] Larhed M., Moberg C., Hallberg A., Microwave-accelerated homogeneous catalysis in organic chemistry. Acc. Chem. Res., 2002, 35, 717-727.

[5] Will H., Scholz P., Ondruschka B., Heterogene Gasphasenkatalyse im Mikrowellenfeld. Chem. Ing. Tech., 2002, 74, 1057-1067.

[6] Lew A., Krutzik P.O., Hart M.E., Chamberlin A.R., Increasing rates of reaction: microwave-assisted organic synthesis for combinatorial chemistry. J. Comb. Chem., 2002, 4, 95-105.

[7] Wathey B, Tierney J, Lidström P, Westman J., The impact of microwave-assisted organic chemistry on drug discovery. Drug Discov. Today, 2002, 7, 373-380.

[8] Blackwell H.E., Out of the oil bath and into the oven-microwaveassisted combinatorial chemistry heats up. Org. Biomol. Chem., 2003, 1, 1251-1255.

[9] Varma R.S., In Advances in green chemistry: Chemical syntheses using microwave irradiation. Astra Zeneca Research Foundation, Kavitha Printers, Bangalore, India, 2002, 35-38.

[10] Kappe C.O., Stadler A., Microwaves in Organic and Medicinal Chemistry. Wiley-VCH, Weinheim, 2005.
[11] Colombo M., Peretto I., Chemistry strategies in early drug discovery: an overview of recent trends. Drug Discov. Today, 2008, 13, 677-684.

[12] Santagada V., Frecentese F., Perissutti E., Fiorino F., Severino B., Caliendo G., Microwave assisted synthesis: A new technology in drug discovery. Mini-Rev. Med. Chem., 2009, 9, 340-358.

[13] Amarasekara A.S., Acidic ionic liquids. Chem. Rev., 2016, 116, 6133-6183.

[14] Giernoth R., Task-specific ionic liquids. Angew. Chem. Int. Ed., 2010, 49, 2834-2839.

[15] Sun X., Luo H., Dai S., Ionic liquids-based extraction: A promising strategy for the advanced nuclear fuel cycle. Chem. Rev., 2012, 112, 2100-2128.

[16] Sawant A.D., Raut D.G., Darvatkar N.B., Salunkhe M.M., Recent developments of task-specific ionic liquids in organic synthesis. Green Chem. Lett. Rev., 2011, 4, 41-54.

[17] QureshiZ.S., Deshmukh K.M., Bhanage B.M., Clean technologies and environmental policy. Clean Technol. Envir., 2014, 16, 14871513.

[18] Hosseinzadeh Z., Ramazani A., Hosseinzadeh K., RazzaghiAsl N., Gouranlou F., An overview on chemistry and biological importance of pyrrolidinone. Current Org. Syn., 2018, 15, 166178.

[19] Feuerstein T.J., Knoerle R., Position-4 substituted 2-pyrrolidinone derivatives to reduce the level of extracellular glutamate. 2002, Patent US 6,384,069 B1.

[20] Geng Y., Wang X., Yang L., Sun H., Wang Y., Zhao Y., et al., Antitumor activity of a 5-hydroxy-1 $H$-Pyrrol-2-(5H)-one-based synthetic small molecule in vitro and in vivo. PLoS One, 2015, 10, 1-15.

[21] Ma K., Wang P., Fu W., Wan X., Zhou L., Chu Y., et al., Rational design of 2-pyrrolinones as inhibitors of HIV-1 integrase. Bioorg. Med. Chem. Lett., 2011, 21, 6724-6727.

[22] Pendri A., Troyer T.L., Sofia M.J., Walker M.A., Naidu B.N., Banville J., et al., Solid phase synthesis of novel pyrrolidinedione analogs as potent HIV-1 integrase inhibitors. J. Comb. Chem., 2010, 12, 84-90.

[23] Gein V.L., Armisheva M.N., Rassudikhina N.A., Vakhrin M.I., Voronina E.V., Synthesis and antimicrobial activity of 1-(4-hydroxyphenyl)-4-acyl-5-aryl-3-hydroxy-3-pyrrolin-2-ones. Pharm. Chem. J., 2011, 45, 162-164.

[24] Franco M.S.F., Casagrande G.A., Raminelli C., Moura S., Rossatto M., Quina F.H., et al., Ultrasound-promoted environmentally friendly synthesis of 5-(3,3,3-trifluoro-2-oxopropylidene) pyrrolidin-2-ones. Synth. Commun., 2015, 45, 692-701.

[25] Choi D.R., Lee K.Y., Chung Y.S., Joo J.E., Kim Y.H., Oh C.Y., et al., Diastereoselective synthesis of polysubstituted pyrrolidinone as a key intermediate for the anticancer agents by palladium(II)catalyzed carboxylation. Arch. Pharm. Res., 2005, 28, 151-158.

[26] Overman L.E., Remarchuk T.P., Catalytic asymmetric intramolecular aminopalladation: Enantioselective synthesis 
of vinyl-substituted 2-oxazolidinones, 2-imidazolidinones, and 2-pyrrolidinones. J. Am. Chem. Soc., 2002, 124, 12-13.

[27] Singh V., Saxena R., Batra S., Simple and efficient synthesis of substituted 2-pyrrolidinones, 2-pyrrolones, and pyrrolidines from enaminones of Baylis-Hillman derivatives of 3-isoxazolecarbaldehydes. J. Org. Chem., 2005, 70, 353-356.

[28] Sarkar R., Mukhopadhyay C., Admicellar catalysis in multicomponent synthesis of polysubstituted pyrrolidinones. Tetrahedron Lett., 2013, 54, 3706-3711.

[29] Sun J., Wu Q., Xia E.Y., Yan C.G., Molecular diversity of threecomponent reactions of aromatic aldehydes, arylamines, and acetylenedicarboxylates. Eur. J. Org. Chem., 2011, 2011, 2981. 2986.

[30] Zhu Q., Jiang H., Li J., Liu S., Xia C., Zhang M., Concise and versatile multicomponent synthesis of multisubstituted polyfunctional dihydropyrroles. J. Comb. Chem., 2009, 11, 685696.

[31] Khaligh N.G., 4-(Succinimido)-1-butane sulfonic acid as a Brönsted acid catalyst for synthesis of pyrano[4,3-b]pyran derivatives under solvent-free conditions. Chin. Chem. Lett., 2015, 26, 26-30.

[32] Khaligh N.G., Abd Hamid S.B., Titinchi S.J.J., Succinimide- $N$ sulfonic acid as a recyclable Brönsted acid catalyst for synthesis of pyrano[4,3-b]pyran derivatives by using solar energy under solvent-free conditions. Polycycl. Arom. Comp., 2017, 37, 31-38.

[33] Khaligh N.G., 1,1'-butylenebis(3-methyl-3H-imidazol-1-ium) hydrogen sulfate catalyzed one-pot multi-component synthesis of unsymmetrical polyhydroquinoline derivatives. Polycycl. Arom. Comp., 2016, 36, 284-294.

[34] Khaligh N.G., Synthesis and characterization of novel binuclear task-specific ionic liquid: an efficient and sustainable sulfonicfunctionalized ionic liquid for one-pot synthesis of xanthenes. Res. Chem. Intermed., 2018, 44, 4045-4062.

[35] Khaligh N.G., Mihankhah T., Johan M.R., Ching J.J., Two novel binuclear sulfonic-functionalized ionic liquids: Influence of anion and carbon-spacer on catalytic efficiency for one-pot synthesis of bis(indolyl)methanes. J. Mol. Liq., 2018, 259, 260-273.

[36] Strauss C.R., Rooney D.W., Accounting for clean, fast and high yielding reactions under microwave conditions. Green Chem., 2010, 12, 1340-1344.

[37] Kappe C.O., Microwave dielectric heating in synthetic organic chemistry. Chem. Soc. Rev., 2008, 37, 1127-1139.

[38] Lidström P., Tierney J., Wathey B., Wetman J., Microwave assisted organic synthesis-A review. Tetrahedron, 2001, 57, 9225-9283.

[39] Castellano T.G., Neo A.G., Marcaccini S., Marcos C.F., Enols as feasible acid components in the Ugi condensation. Org. Lett., 2012, 14, 6218-6221.

[40] Yang J., Tan J.N., Gu Y., Lactic acid as an invaluable biobased solvent for organic reactions. Green Chem., 2012, 14, 3304-3317.

[41] Ahankar H., Ramazani A., Ślepokura K., Lis T., Joo S.W., Synthesis of pyrrolidinone derivatives from aniline, an aldehyde and diethyl acetylenedicarboxylate in an ethanolic citric acid solution under ultrasound irradiation. Green Chem., 2016, 18, 3582-3593.

[42] Connors K.A., Structure Reactivity Relationships: the Study of reaction rates in solution (Chapter 7). VCH Publishers, New York, 1990, p 311.

[43] Flores A.C., Flores E.A., Hernández E., Castro L.V., García A., Alvarez F., et al., Anion and cation effects of ionic liquids and ammonium salts evaluated as dehydrating agents for superheavy crude oil: Experimental and theoretical points of view. J. Mol. Liq., 2014, 196, 249-257.

[44] Krannich M., Heym F., Jess A., Characterization of six hygroscopic ionic liquids with regard to their suitability for gas dehydration: Density, viscosity, thermal and oxidative Stability, vapor pressure, diffusion coefficient, and activity coefficient of water. J. Chem. Eng. Data, 2016, 61, 1162-1176.

[45] Zonouz A.M., Eskandari I., Notash B., Efficient synthesis of 3-pyrrolin-2-one derivatives in aqueous media. Synth. Commun., 2015, 45, 2115-2121. 